\title{
Emergency Management in Local Government
}

\author{
Rrahim Rexha ${ }^{a}$
}

\begin{abstract}
Natural disasters, in all of their phases, have been and are part of social development processes, where their types describe development stages and their impact is reflected in cultural differences and social development processes. A big impact in this process has also the technological development, which has affected the society to face various crises. Unfortunately, policymakers have not learned a lesson from this and as a result, they do not prepare themselves and public to react adequately against these crises. Facts indicate that technological advancement created the possibility of presenting different development sizes of catastrophe. As a result, our planet represents "the world of danger" since development activities in one place affect the population outside its borders. This applies to natural and technological disasters, like: earthquakes, floods, fires, industrial and nuclear incidents, etc. Dynamical developments of our time require clarification of some problems which are very important for the security of every human being but also for the country and functioning of its security system. Although these cases are managed on daily basis at the lowest possible geographical, organizational, and legal level, again there are circumstances in which successful operations in managing an incident depend on the involvement of many governmental levels, functional agencies, and emergy response. These circumstances required effective and efficient reaction between a citizen as the first one to face the danger and local government bodies which are obligated for his protection.
\end{abstract}

\section{Keywords}

Emergency, natural disasters, legal, municipality, local government

In today's modern world, dispite the major technical and technological development, people are now at risk not only from extreme geophysical events, such as earthquakes and floods, but also by physical explosions, the release of toxins and major accidents in traffic and continuous destruction caused from natural disasters.

Security challenges from these disasters affect all countries, regardless of the system of organization to deal with these phenomena. They do not choose the time and place where it will occur. All countries of the world regardless of economic development, are endangered by various risks that threaten national security interests.

Events are caused by the uncontrolled action of natural forces, and the human factor that endanger the lives and health of people and animals, causing damage to property, cultural heritage, and the environment. The Republic of Kosovo is not exempt from these threats, although so far has not been hited by any major natural disaster, another disaster or catastrophe.

Technical and technological development worldwide, on the one hand, has reached its positive effects on the development and improvement of lifestyle, but on the other hand, in certain cases, it

aAAB College, Kosovo

\section{Correspondent Author:}

Rrahim Rexha, Fushtic E Poshtme, Drenas, Region of Pristina, Republic of Kosova

E-mail: rrahim.rexha@universitetiaab.com 
appears to us as a potential risk for life, safety, and human health. In contemporary terminology, these disasters are classified with its name "man-made" (the human factor), while recent years, almost all the disasters even of some who until now known as natural disasters, are trying to argue as a disastres affected by human factor. This type of disasters caused by the human factor, belong the consequences of terrorist attacks, which represent a new form of threat in the twenty-first century.

The legal framework of civil emergency management is regulated by a series of laws and sub-legal acts, starting from constitution to special laws: (1) while management system of emergencies is realized through the Integrated System for Emergency Management; (2) which provides a consistent nationwide framework to enable the governments of both levels, non-governmental organizations (NGOs) and the private sector work together for prevention, protection, response, recovery, and mitigation of the effects of incidents, regardless of their cause, size, location, or complexity.

Also, it is drafted and approved the National Response Plan, which includes all sorts of dangers, having aimed at a comprehensive national approach to emergency management, with the prevention, preparedness, response, and recovery.

According to the Constitution of the Republic of Kosovo (Article 12), the basic territorial units of local government in the Republic of Kosovo are municipalities. The municipality is an administrative-territorial and community residents. Regards the organization, it consists of two basic authorities: the municipal assembly and the mayor. The organization of these two bodies enables complementary operation to each other, and both bodies are elected directly by the citizens vote. This manner of selection has dictated a high degree of autonomy of the work of municipal bodies. Compared with countries in region and the majority of European countries, the Republic of Kosovo municipalities have acquired some competences from the central government.

In the Republic of Kosovo, local government is based on the principles of good governance, transparency, subsidiarity, providing services efficiently and effectively, paying special attention to the needs and concerns of specific communities who are not the majority and their members ${ }^{1}$. The principle of local autonomy now being replaced by the principle of local self-government, the autonomy is being identified as a way of federalism of local units and removal of direct interest of citizens. Kosovo's local government is trying to implement into practice all the principles of the EU (European Union) countries, by adopting them to the current circumstances.

In the fields of civil management emergencies, municipalities faced the situations where Emergency Management of Integrated System (EMIS) has not been respected. Once the emergency events start at the municipal level, which means that the responsibility lies with the municipality, but if the situation escalates, then competences overcome to the regional centers. If the situation exceeds the capacities of the certain region action, then the request goes to the central level of Emergency Management Agency.

\section{OVERVIEW OF LEGISLATION FOR EMERGENCIES IN KOSOVO}

After the war in Kosovo, since that time, Kosovo was administered under Resolution 1244 of the UN (United Nations), Special Representative for Kosovo has issued Regulation No. 1999/8 on the establishment of the Kosovo Protection Corps, which in Article 1 of this regulation states: Kosovo Protection Corps is established as a civilian emergency service agency, whose main tasks will be:

(1) To provide services in cases of natural disasters;

(2) To perform research and rescue people at danger; 
(3) To provide humanitarian aids in the isolated areas;

(4) To assist in demining mined areas;

(5) To contribute in reconstruction of infrastructure and the communities.

Later on, it is followed by the next regulation where again the Special Representative of the Secretary-General, in accordance with Resolution 1244, issued Regulation No. 2000/61 on the Establishment of the Administrative Department of Civil Security and Emergency Preparedness².

Pursuant to Article 1.2. of the Regulation states: "The department is responsible for coordinating the overall issues relating to the prevention of emergencies and response services in Kosovo, including, but not limited to the Kosovo Protection Bodies, fire services and emergency services as well long-term measures mine clearance” ${ }^{\text {"3 }}$.

Then later, followed the next Regulation No. 2006/3 where there is an amendment, the previous regulation, and now under this regulation, now in Article 1.1 of the regulation states: Kosovo Protection Corps established as a civilian emergency service agency, whose main tasks are:

(1) To provide disaster response services;

(2) To carry out research and rescue activities;

(3) To provide its capabilities in providing humanitarian aids at isolated areas;

(4) To assist in demining;

(5) To contribute to the construction of infrastructure and reconstruction for communities, including monitoring of reconstructed and non-inhabited houses owned by minorities ${ }^{4}$.

\section{Law No. 03/L-040 on Local Self-Government}

Law on local self-government does not provide legal solutions and does not treat so closely disaster management at the local level. This law does not enable and have as a priority the establishment of the Directorate for Protection and Rescue. This law did not clearly define the functioning of the respective departments, it is confirmed on the basis that the law gives to both local and central authorities the right to control and administrate. And that make confusion to this department in the reporting line and responsibilities. The law on the duties and responsibilities of local level disaster management, to mention only one row even though its scope is very broad description, as e.g.:

Article 2-scope. This law defines the legal status of municipalities, their competencies and general principles of municipal finances, organization and functioning of the municipal bodies, the intra-municipal arrangements and the inter-municipal cooperation including the cross border cooperation and the relationship between municipalities and central government"

Regarding the duties and responsibilities, they are described below, and as mentioned above, the management of disasters in this law remains however to be reviewed and amended taking into account that the Republic of Kosovo is as a new state, every more and more will face disaster of all kinds and elected people at local level, they first will deal with these disasters. Below are parts of the law describing their own powers, which are numerous, among them, the authority to manage disasters, which unfortunately is not discussed much.

Even it has the unclear term (local emergency response) which the author is convinced that it is not understandable for most of the officials at the local level in Kosovo, because word response (response) from English, that means intervention during disasters, in Albanian language is translated as an answer. So instead of used terms in the field of disaster management, the law uses the school ordinary term that type of question-answer!

\section{CONCLUSIONS}

In the emergency response plan at the Municipality of Drenas, there are many shortcomings ranging from the 
fact that this plan is not updated nearly eight years, there are shortcomings in clarifying the concrete competences in case of disasters, does not define clearly the responsibility of commendation in case of disasters. It has been observed a distancing of emergency services against local government to the fact that employees of emergency have confusion that under the whom umbrella actually they must be, under the municipal or the Agency for Emergency Management at the Ministry of Internal Affairs. Therefore, it has come to the neglect to all processes which supposed to be developed under this directorate.

Dangerous situations and circumstances exist in all communities without exception, from chemical leaks, nuclear accidents up to the threat. They are ranged under natural hazards such as: storms and floods to terrorist events. Generally, ordinary citizens pay little attention to these potential risks until occur or threaten our communities. Local Directories for Protection and Rescue (LDPR) have the responsibility of identifying the actual and potential risks, and to the possible greatest extent to prepare plans in order to cope with them when they occur and during their occurrence.

The Municipal Emergency Operations Plan represents harmonized attempt of consolidated municipal government to provide resources and assistance expeditiously for saving lives and protecting the goods from all risks.

Local Emergency Planning of all the risks outlines the actions needed to be undertaken in response to a disaster, including immediate and potential threats of each event. Further, this facilitates planning for coordination of resources distribution and providing the municipal services, necessary to face the consequences of the disaster. Planning outlines the planning assumptions, policies, concept of operations, organizational structures and specific responsibilities of departments and entities charged with the local emergency response.
Planning for disaster should be in accordance with the basic plan outlined in the guidance of the Emergency Management Agency under the Ministry of Internal Affairs of the Republic of Kosovo, and must be in accordance with the standards and principles acceptable to the EMIS and the concept of the Emergency Operations Center.

\section{Notes}

1. The Assembly of Kosovo, the Constitution of the Republic of Kosovo, Article 123, Paragraph 4 and Article LVL 15.

2. UNMIK Regulation No. 2000/61 dated November 9, 2000.

3. Reg. 2000/61 Article 1.2 dated November 9, 2000.

4. Reg. $2006 / 3$ to change the Reg. No. $1999 / 8$ on the establishment of the Kosovo Protection Corps, January 26, 2006.

5. Law No. 03/L-040 on Local Self Government, Article 2, page 3 .

\section{References}

Administrative Instruction and Stablishment Criteria for Organization of Fire Services and Rescue in Kosovo No.05/2007. N.d. Pristine.

Assembly of Kosovo. N.d. The Constitution of the Republic of Kosovo. Article 123, Paragraph 4 and Article LVL 15.

Banks, E. 2005. Catastrophic Risk. Chichester: John Wiley \& Sons, Ltd.

Banks, E. and R. Dunn. 2003. Practical Risk Management. Danvers, USA: Wiley.

Emergency Management of Integrated System (EMIS). 2010. Road Transport Law No. 2004/1. Prishtina.

Law on Fire Protection (No. 2006/02-L41). N.d.

Law on Protection Against Natural and Other Disasters (No. 2006/02/L-68). N.d.

Law on the Ministry for the Kosovo Security Force No. 2008/03-L045. N.d.

Molak, V. 1997. Fundamentals of Risk Analysis and Risk Management. USA: CRC Press.

Official Gazette of the Republic of Kosovo. 2000. Reg. 2000/61 Article 1.2. November 9. Republic of Kosovo.

- 2006. Reg. 2006/3 to Change the Reg. No. 1999/8 on the Establishment of the Kosovo Protection Corps. January 26. Republic of Kosovo.

- 2008. Law No. 03/L-040 on Local Self Government. Article 2, page 3. Republic of Kosovo. 
N.d. Administration Instruction No. 18/2010 MIA on Organization and Structure of Emergency Menagment Agency. Republic of Kosovo.

- N.d. Law No. 02/L-68 for Protection Against Natural and Other Disaster. Republic of Kosovo.

Police Law No. 03/L-035. N.d.

UNMIK Regulation No. 2000/61. 2000. November 9. Pristina.

\section{Bio}

Rrahim Rexha, BA in political sciences, Public University of Pristina, MA in public administration and diplomacy, AAB College, Pristina, Kosovo; research fields: emergency managment, local government, preservation of traces at the explosion place, interconnection between governments in case of any emergency, etc. 